\title{
CHARACTERIZATION OF THE GENOTYPE AND THE PHENOTYPE OF NONTOXIGENIC STRAINS OF CORYNEBACTERIUM DIPHTHERIAE SUBSP. LAUSANNENSE ISOLATED IN RUSSIAN RESIDENTS
}

Borisova OYu1,2凶, Chaplin AV ${ }^{1,2}$, Gadua NT ${ }^{1}$, Pimenova AS ${ }^{1}$, Alexeeva IN ${ }^{3}$, Rakitsky $\mathrm{GF}^{3}$, Afanasiev SS ${ }^{1}$, Donskikh EE ${ }^{2}$, Kafarskaya $\mathrm{LI}^{2}$

1 G. N. Gabrichevsky Research Institute for Epidemiology and Microbiology, Moscow, Russia

2 Pirogov Russian National Research Medical University, Moscow, Russia

${ }^{3}$ Regional Clinical Psychiatric Hospital, Khabarovsk, Russia

In 2018, a few sequencing studies were published revealing the existence of two monophyletic clusters within the C. diphtheriae species, meaning that this species can be divided into two subspecies: C. diphtheriae subsp. diphtheriae and C. diphtheriae subsp. lausannense. The objective of our study was to describe the genotype and the phenotype of 2 nontoxigenic C. diphtheriae strains isolated in Russia in 2017-2018, which were classified by us as C. diphtheriae subsp. lausannense based on the aggregated data yielded by a variety of techniques, including microbiological and molecular genetic techniques, as well as a bioinformatic search for subspecies-specific genes in the publicly available genomes of $C$. diphtheriae. The isolated strains had morphological and biochemical characteristics of C. diphtheriae. The strains were assigned to the MLST type ST199 included in the clonal complex associated with subsp. lausannense. PCR revealed that both analyzed strains of $C$. diphtheriae subsp. lausannense carried the ptsl gene encoding phosphoenolpyruvate-protein phosphotransferase and did not carry the narG gene encoding the synthesis of nitrate reductase subunits, whereas the strains of $C$. diphtheriae subsp. diphtheriae had the narG gene and did not have pts/. We experimentally proved the ability of lausannense strains to ferment $\mathrm{N}$-acetylglucosamine. Our findings expand the knowledge of the biological diversity of C. diphtheriae and indicate the need for estimating the spread of these microorganisms in Russia, as well as their pathogenic potential.

Keywords: diphtheria, nontoxigenic Corynebacterium diphtheriae, Corynebacterium diphtheriae subsp. lausannense, multilocus sequence typing, phylogenetic analysis

Author contribution: Borisova OYu carried out molecular genetic tests, analyzed the literature and the obtained data, contributed to manuscript preparation; Chaplin AV performed phylogenetic analysis, analyzed the experimental data and contributed to manuscript preparation; Gadua NT, Pimenova AS carried out microbiological tests and contributed to manuscript preparation; Alexeeva IN, Rakitsky GF examined the patients on admission and contributed to manuscript preparation; Afanasiev SS conducted molecular genetic tests and contributed to manuscript preparation; Donskikh EE analyzed the literature and the experimental data and contributed to manuscript preparation; Kafarskaya LI analyzed the experimental data and contributed to manuscript preparation.

Compliance with ethical standards: the study was approved by the Ethics Committee of G. N. Gabrichevsky Research Institute for Epidemiology and Microbiology. Informed consent was obtained from all participants.

$\triangle$ Correspondence should be addressed: Olga Yu. Borisova Admirala Makarova, 10, Moscow, 125212; olgborisova@mail.ru

Received: 09.02.2020 Accepted: 28.02.2020 Published online: 18.03.2020

DOI: $10.24075 /$ brsmu.2020.015

\section{ХАРАКТЕРИСТИКА ГЕНОТИПА И ФЕНОТИПА НЕТОКСИГЕННЫХ ШТАММОВ CORYNEBACTERIUM DIPHTHERIAE SUBSP. LAUSANNENSE, ВЫДЕЛЕННЫХ НА ТЕРРИТОРИИ РОССИИ}

О. Ю. Борисова ${ }^{1,2}$, А. В. Чаплин ${ }^{1,2}$, Н. Т. Гадуа ${ }^{1}$, А. С. Пименова ${ }^{1}$, И. Н. Алексеева ${ }^{3}$, Г. Ф. Ракицкий , С. С. Афранасьев ${ }^{1}$ Е. Е. Донских², Л. И. Карарская²

Московский научно-исследовательский институт эпидемиологии и микробиологии имени Г. Н. Габричевского, Москва, Россия

2 Российский национальный исследовательский медицинский университет имени Н. И. Пирогова, Москва, Россия

${ }^{3}$ Краевая клиническая психиатрическая больница, Хабаровск, Россия

В 2018 г. на основании полногеномных данных появились публикации о наличии двух монофилетических кластеров внутри вида C. diphtheriae, что позволяет дифференцировать этот вид на два подвида: C. diphtheriae subsp. diphtheriae и C. diphtheriae subsp. lausannense. Целью работь было описать генотип и фенотип двух нетоксигенных штаммов C. diphtheriae, выделенных в 2017-2018 гг. с профилактической целью, которые на основании совокупности результатов множества методов могут быть отнесены к C. diphtheriae subsp. lausannense. В исследовании использовали микробиологические и молекулярно-генетические методы, а также биоинформатический поиск подвид-специфичных генов в публично доступных геномах C. diphtheriae. Выделенные штаммы имели характерные для C. diphtheriae морфо-культуральные свойства и биохимическую характеристику. В МЛСТ штаммы принадлежали к сиквенс-типу ST199, входящему в клональный комплекс, ассоциированный с subsp. lausannense. C использованием ПЦР были показаны наличие pts/ (гена, кодирующего фосфоенолпируват-белок фосфотрансферазы) и отсутствие пагG (гена, кодирующего синтез субъединиц нитратредуктазы) у двух исследуемых штаммов C. diphtheriae subsp. lausannense и противоположная картина - у штаммов C. diphtheriae subsp. diphtheriae. Была экспериментально подтверждена способность выделенных штаммов подвида lausannепsе сбраживать $\mathrm{N}$-ацетилглюкозамин. Полученные результаты расширяют представления о биологическом разнообразии вида C. diphtheriae и свидетельствуют о необходимости дальнейших исследований по оценке распространенности этих микроорганизмов и изучению их патогенного потенциала.

Ключевые слова: дистерия, нетоксигенные Corynebacterium diphtheriae, Corynebacterium diphtheriae subsp. lausannense, мультилокусное секвенирование, филогенетический анализ

Вклад авторов: О. Ю. Борисова - молекулярно-генетические исследования, анализ данных, анализ литературы, подготовка рукописи; А. В. Чаплин филогенетический анализ, анализ данных, подготовка рукописи; Н. Т. Гадуа и А. С. Пименова - микробиологические исследования, подготовка рукописи; И. Н. Алексеева и Г. Ф. Ракицкий - обследование пациентов и первичная идентификация, подготовка рукописи; С. С. Афанасьев молекулярно-генетические исследования, подготовка рукописи; Е. Е. Донских - анализ данных, анализ литературы, подготовка рукописи; Л. И. Кафарская - анализ данных, подготовка рукописи.

Соблюдение этических стандартов: исследование одобрено этическим комитетом Московского научно-исследовательского института эпидемиологии и микробиологии имени Г. Н. Габричевского. Все пациентки подписали добровольное информированное согласие на участие в исследовании.

$\triangle$ Для корреспонденции: Ольга Юрьевна Борисова ул. Адмирала Макарова, д. 10, г. Москва, 125212; olgborisova@mail.ru

Статья получена: 09.02.2020 Статья принята к печати: 28.02.2020 Опубликована онлайн: 18.03.2020

DOI: 10.24075/vrgmu.2020.015 
Diphtheria is caused by toxigenic strains of Corynebacterium diphtheriae harboring integrated bacteriophage DNA containing the toxin gene. The infection spreads from person to person via airborne droplets and develops into classic pharyngeal or nasal diphtheria.

Over the past century, mass immunization programs have dramatically cut down the incidence of diphtheria [1]. In Russia, the incidence rate of the disease has stabilized due to good vaccination coverage ( $\geq 95 \%$ ) [2]. In 2017, no incident cases of diphtheria and only 2 asymptomatic carriers were reported in Russia. In 2018, 4 incident cases of the disease and 3 carriers were reported, whereas in the first 9 months of 2019, there were 3 new cases of diphtheria and 2 carriers [3]. In the past few years, there have been no reports of the secondary cases or lethal infection. Most clinical forms of diphtheria are mild localized forms.

Today, diphtheria is a rare disease; therefore, it can pose a diagnostic difficulty to the clinician. This, as well as the existence of latent carriers, who act as a reservoir for the infection, and the fact that the epidemic process unfolds in the vaccinated population, still renders diphtheria a clinically important problem [3].

Recently, infections caused by nontoxigenic $C$. diphtheriae strains have been on the rise. They manifest atypically as pharyngitis, respiratory tract infections, endocarditis, osteomyelitis, septic arthritis or skin infections [4-8].

Historically, C. diphtheriae were classified into 4 biotypes based on their biochemical phenotypes: gravis, mitis, intermedius and belfanti $[9,10]$. Representatives of the same biovar, though, can be genetically distant $[11,12]$. This is why genomics does not support the use of biovars as a reliable classification tool for $C$. diphtheriae [13]. Besides, there is no correlation between the biovar and pathogenicity [14]. Multilocus sequence typing (MLST) based on the determination of allelic profiles of 7 housekeeping genes has made it possible to cluster the entire diversity of $C$. diphtheriae strains into 2 evolutionary lineages: lineage-1 (the majority of the strains) and lineage-2 (only strains of the belfanti biotype) [14].

In 2018, a paper was published describing 3 nontoxigenic strains of $C$. diphtheriae [15]. One of them had been isolated from a Swiss patient with tracheobronchitis and multiple lesions on the distal trachea and the mainstem bronchi; the 2 other strains had been isolated from nasal swabs in the UK and India. Genome comparison that used publicly available C. diphtheriae genomes demonstrated that average nucleotide identity between the isolated strains and the NCTC 11397 C. diphtheriae reference genome was lower (95.24 to 95.39\%) than between the reference genome and other previously published C. diphtheriae genomes (> 98.15\%). Phylogeny reconstruction based on whole genome sequencing data confirmed the existence of two monophyletic clusters of C. diphtheriae corresponding to lineage-1 and lineage-2. Consequently, it was proposed to classify C. diphtheriae into two subspecies: C. diphtheriae subsp. diphtheriae and C. diphtheriae subsp. lausannense.

The aim of this study was to characterize the genotype and the phenotype of nontoxigenic $C$. diphtheriae strains isolated in 2017-2018 that can be identified as C. diphtheriae subsp. lausannense based on the aggregated data yielded by a variety of different methods.

\section{METHODS}

In the experimental part of the study, we analyzed 2 nontoxigenic C. diphtheriae strains isolated at the bacteriological laboratory of Khabarovsk Regional Psychiatric Hospital in 2017-2018, the control toxigenic strain of $C$. diphtheriae (gravis biotype, accession number 665) from the State collection of pathogenic microorganisms (SCPM-Obolensk), freshly isolated toxigenic strains of $C$. diphtheriae (gravis biotype, strain numbers 6619, 98-19 and mitis biotype, strain numbers 55-19, 56-19), nontoxigenic strains of $C$. diphtheriae (gravis biotype, strain numbers 57-19, 67-19 and mitis biotype, strain numbers 6019, 91-19) that had been delivered to the Reference Center for the Surveillance of Measles, Rubella, Mumps, Pertussis, and Diphtheria (G.N. Gabrichevsky Research Institute for Epidemiology and Microbiology) from different Russian regions.

The analysis of $C$. diphtheriae strains was conducted following the guidelines № 4.2.3065-13 for laboratory diagnostics of diphtheria. The isolates were plated onto tellurite blood agar (2\% fishmeal hydrolysate agar base, State Research Center for Applied Microbiology \& Biotechnology; Obolensk; Russia) supplemented with $7 \%$ bovine blood (Leitran; Russia) and potassium tellurite (State Research Center for Applied Microbiology \& Biotechnology; Obolensk, Russia) and kept in a temperature-controlled chamber at $37^{\circ} \mathrm{C}$ for 24-48 hours. Grown colonies of $C$. diphtheriae were evaluated for their morphological, toxigenic and biochemical properties. The toxigenicity of $C$. diphtheriae strains was evaluated in a precipitation test using a Corynetoxagar medium (State Research Center for Applied Microbiology \& Biotechnology; Obolensk, Russia) supplemented with $20 \%$ bovine serum (Leitran; Russia) and filter discs soaked in diphtheria antitoxin (Diagnostic Systems; Nizhny Novgorod, Russia). Each antitoxinimpregnated disc contained $5 \pm 1 \mathrm{IU}$ of diphtheria antitoxin (as suggested by the guidelines 4.2.3065-13). Biochemical properties of the cultures were determined from their cysteinase, urease, saccharolytic and nitrate reductase activity using the media prepared at our laboratory and a commercial DS-DIPHCORYNE kit (Diagnostic Systems; Nizhny Novgorod, Russia).

To evaluate the ability of the analyzed strains to ferment $\mathrm{N}$-acetylglucosamine, a phenol red broth was ex tempore supplemented with $\mathrm{N}$-acetylglucosamine (Sigma-Adlrich; USA). Then, a loop full of overnight $C$. diphtheriae cultures grown on serum agar was added to $3 \mathrm{ml}$ of the solution. The cultures were incubated at $37^{\circ} \mathrm{C}$ for $24-48 \mathrm{~h}$. Fermentation was evaluated based on the change in the color of the solution. Two toxigenic and two nontoxigenic gravis strains, as well as two toxigenic and two nontoxigenic mitis strains, were used as controls.

The sample of the analyzed published genomic sequences comprised 204 C. diphtheriae genomes representing diphtheriae and lausannense subspecies deposited in the $\mathrm{NCBI}$ Refseq database, 3 genomes of $C$. diphtheriae subsp. lausannense from the NCBI Genbank and one genome of Corynebacterium ulcerans BR-AD22, which served as an outgroup for phylogenetic reconstruction. In total, 208 genomes were included in the analyzed dataset.

Coding sequences retrieved from the genome annotations in the corresponding databases were clustered into ortholog groups using OrthoMCL [16] with standard settings (inflation index of 1.5; protein sequence similarity threshold of $50 \%$; e-value of 10-5). For phylogeny reconstruction, we used the groups of orthologs that were made up of the genes present in every genome in the amount of 1 copy. Nucleotide sequences were aligned in MUSCLE software [17] and then concatenated. Phylogeny reconstruction was performed following the Maximum Likelihood algorithm implemented in FastTree software [18] using the GTR+CAT model. MLST types of the published sequences were predicted based on the 
data retrieved from PubMLST. Clonal clusters were formed in Phyloviz 2 using the goeBURST algorithm at the SLV level [19].

Total DNA was isolated from overnight C. diphtheriae cultures grown on fishmeal hydrolysate agar (State Research Center for Applied Microbiology \& Biotechnology; Obolensk, Russia) supplemented with 10\% bovine serum (Leitran; Moscow) using a standard boiling extraction method with subsequent centrifugation.

Detection of tox gene fragments in nontoxigenic C. diphtheriae strains was performed in accordance with the protocol described in [20]. The PCR reaction mix contained $1.5 \mathrm{mM}$ $\mathrm{MgCl}_{2}, 10 \mathrm{mM}$ Tris- $\mathrm{HCl}$ ( $\mathrm{pH}$ 8.3), $50 \mathrm{mM} \mathrm{KCl}, 0.1 \mu \mathrm{M}$ of forward and reverse primers, $200 \mathrm{mM}$ of each dNTP, and 1 unit of Taq polymerase (Thermo Fisher Scientific; USA). DNA of the control toxigenic $C$. diphtheriae strain (gravis biovar, accession number 665) was used as a positive amplification control. MLST types of $C$. diphtheriae strains were determined following the international protocol [14]; fragments of 7 housekeeping genes were Sanger-sequenced, including atp $A$, dnaE, dnaK, fus $A$, leuA, odhA, and rpoB. Sequencing was carried out by Evrogen JSC (Moscow). Allele identification was done using the PubMLST database.

To identify $d t x R$ fragments in the sequences of $C$. diphtheriae strains, PCR was carried out with one pair of primers for the entire region of the $d t x R$ gene: GGGACTACAACGCAACAAGAA and TCATCTAATTTCGCCGCCTTA as described in [20, 21]. The following primers were used for subspecies-specific PCR: ptsl_F: ACTTTCCGAACCTGCCATCC and ptsl_R:GTGTACTCCT TCGTCTGCTC; narG_F: CTGACCACTGGGGCGAGG and narG_R: GAGTTGTCATAACGCCACTG.

\section{RESULTS}

The C. diphtheriae strains B-8759 and B-8760 had been isolated from the pharynx of two patients ( 26 and 77 years) admitted to 2 different units of a psychiatric hospital; the patients had undergone a standard preadmission test for diphtheria (see Paragraph 3.4. of the Guidelines 3.1.3018-12 on the epidemiological surveillance of diphtheria infection). The isolated strains were identified from their morphological, toxigenic and biochemical properties as recommended by the Guidelines 4 .2.3065-13 on the laboratory diagnostics of diphtheria. On tellurite blood agar, the grown colonies appeared grayish-black, fuzzy, crumbly, with slightly irregular margins and a raised center. Toxigenicity of the grown colonies was determined using discs impregnated with diphtheria antitoxin (the Feldman method). After 24 and 48 hours of incubation, the

Table 1. Characteristics of the analyzed $C$. diphtheriae cultures isolated cultures still had not produced specific precipitation lines, unlike the control toxigenic C. diphtheriae strain (gravis biotype, accession number 665), suggesting the absence of toxigenicity. PCR performed to detect the fragment of the tox gene demonstrated that the analyzed strains did not carry the diphtheria toxin gene.

Biochemical properties of the cultures were determined from their cysteinase, urease, saccharolytic and nitrate reductase activity. The cultures exhibited cysteinase activity and formed a brown halo following inoculation into the Pisu medium; the cultures fermented glucose, maltose, fructose and galactose, did not ferment saccharose and starch, and exhibited no urease or nitrate reductase activity (Table 1). The tests allowed us to provisionally assign the analyzed $C$. diphtheriae strains to the belfanti biotype typically seen in lausannense subspecies.

In the next step, we analyzed the previously published genomes of $C$. diphtheriae, which was necessary to verify that the studied species can be distinctly divided into subspecies and to conduct a search for species-specific protein-encoding genes.

The constructed phylogenetic tree (Fig. 1) confirmed the results previously obtained on a smaller sample indicating that representatives of $C$. diphtheriae constituted two clades corresponding to the subspecies diphtheriae and lausannense. The tree also showed that the representatives of these subspecies belonged to non-overlapping groups of sequence types. The goeBURST clustering analysis of MLST types described in PubMLST (Fig. 2) revealed that all representatives of the lausannense subspecies whose genomes had been previously sequenced belonged to the sequence types ST106, ST360, or ST409, and to one previously undescribed type that differed from ST359 in just one allele. All these sequence types formed one clonal complex.

It could be hypothesized that other sequence types (such as ST35, ST37, ST69, or ST81) constituting the same clonal complex also belong to the lausannense subspecies. An additional argument in favor of our hypothesis is that almost all isolates representing the sequence types from this clonal complex have been described in the PubMLST database as representing the belfanti biotype typical to the lausannense subspecies.

The analysis of ortholog groups revealed the existence of loci specific to $C$. diphtheriae subspecies. For example, all strains of the lausannense subspecies had a region (presumably, an operon) harboring genes of the phosphotransferase system, for which $\mathrm{N}$-acetylglucosamine is a hypothesized substrate. The following primers were selected for the gene coding

\begin{tabular}{|c|c|c|c|}
\hline \multirow{2}{*}{ Characteristic } & \multicolumn{3}{|c|}{ C. diphtheriae strains } \\
\hline & Strain 665 (control) & Strain B-8759 & Strain B-8760 \\
\hline Glucose fermentation & + & + & + \\
\hline Saccharose fermentation & - & - & - \\
\hline Maltose fermentation & + & + & + \\
\hline Fructose fermentation & + & + & + \\
\hline Galactose fermentation & + & + & + \\
\hline Starch fermentation & + & - & - \\
\hline Urease & - & - & - \\
\hline Nitrate reductase & + & - & - \\
\hline Cysteinase test & + & + & + \\
\hline Toxigenicity (the Feldman method) & + & - & - \\
\hline Presence of the tox gene & + & - & - \\
\hline
\end{tabular}




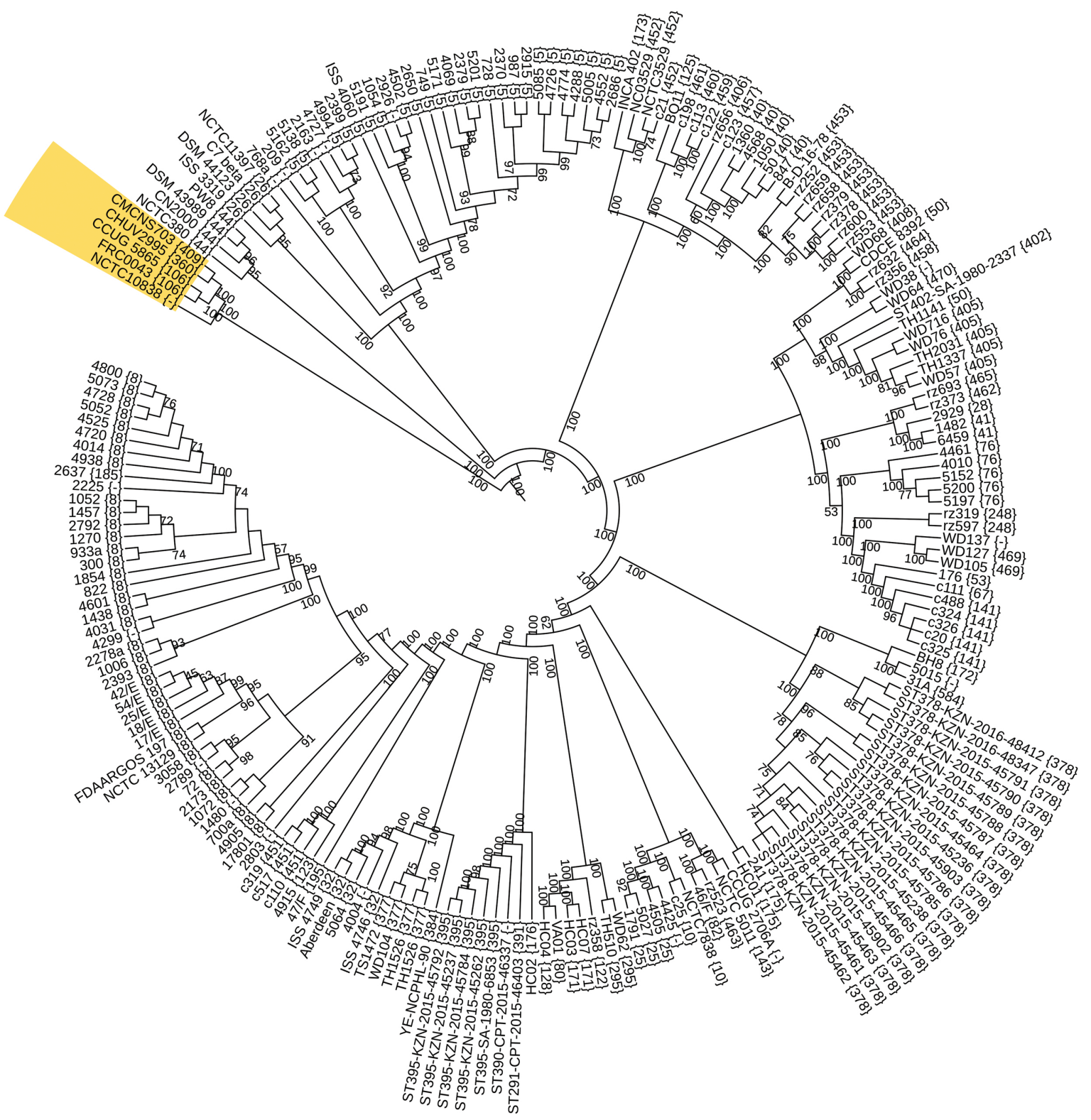

Fig. 1. A phylogenetic tree for $C$. diphtheriae strains with publicly available sequenced genomes. The length of the branches and the genome of $C$. ulcerans BR-AD22 used for rooting are not shown in the figure. The numbers on the branches represent bootstrap values. Strains of $C$. diphtheriae subsp. lausannense are shown in gray. The numbers in brackets refer to the predicted sequence types and follow the PubMLST nomenclature (dash marks represent yet undescribed sequence types)

for phosphoenolpyruvate-protein phosphotransferase: pts/_F: ACTTTCCGAACCTGCCATCC and ptsI_R: GTGTACTCCTTCGTCTGCTC (the expected product length was 489 bp). At the same time, a locus encoding the synthesis of nitrate reductase subunits was detected only in the genomes of the diphtheriae subspecies. The following primers were selected for the gene encoding its $\alpha$-subunit (the gene was present in the sequences of 201 out of 202 strains representing this subspecies in the analyzed sample): narG_F: CTGACCACTGGGGCGAGG and narG_R: GAGTTGTCATAACGCCACTG (the expected product length was $691 \mathrm{bp})$.

PCR with primers for the amplification of pts/ and narG fragments (Fig. 3) showed that the samples containing DNA of B-8759 and B-8760 strains carried the pts/ gene and did not carry the narG gene, whereas "classic" C. diphtheriae strains had the narG gene and did not have pts/. There were no samples that carried either both of these genomic loci or none of them.

These findings and the results of biochemical identification allowed us to conclude that the analyzed C. diphtheriae strains belonged to $C$. diphtheriae subsp. lausannense. The conclusion was corroborated by the fact that the isolated strains represented the sequence type ST199 included in the clonal complex presumably typical to the representatives of this subspecies (Fig. 2). Another piece of evidence confirming our conclusion was the sequence of the $d t x R$ gene that coincided with the sequences found in the genomes of lausannense subspecies.

Considering that strains of $C$. diphtheriae subsp. lausannense carried the gene coding for phosphoenolpyruvateprotein phosphotransferase, which is part of the phosphotransferase system for $\mathrm{N}$-acetylglucosamine, we conducted a few experiments to investigate the phenotypic manifestations of this gene. The experiments showed that unlike $C$. diphtheriae subsp. diphtheriae, both analyzed strains, which we classified as C. diphtheriae subsp. lausannense, fermented $\mathrm{N}$-acetylglucosamine (Fig. 4).

The analyzed strains, which we classified as $C$. diphtheriae subsp. lausannense, were deposited in the State collection of pathogenic microorganisms (SCPM-Obolensk). 


\section{ORIGINAL RESEARCH I MICROBIOLOGY}

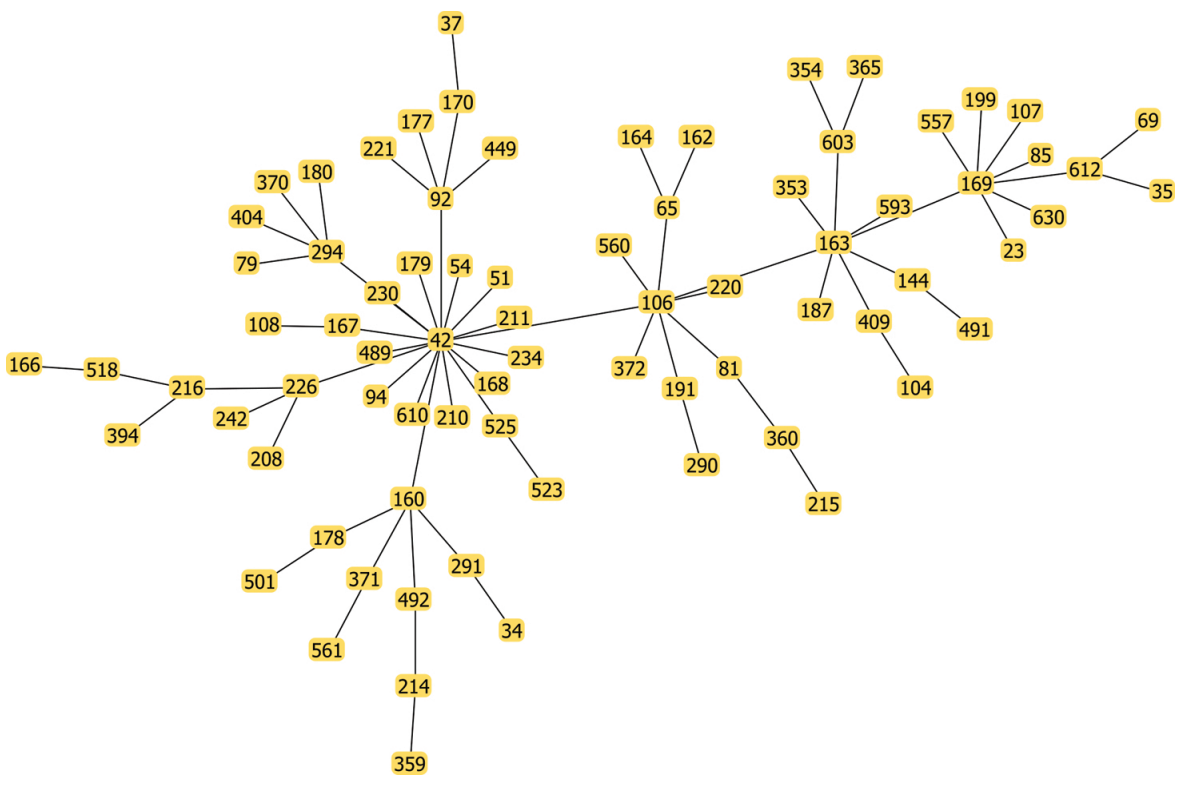

Fig. 2. The clonal complex reconstructed from PubMLST data. The complex comprises lausannense strains with publicly available sequenced genomes

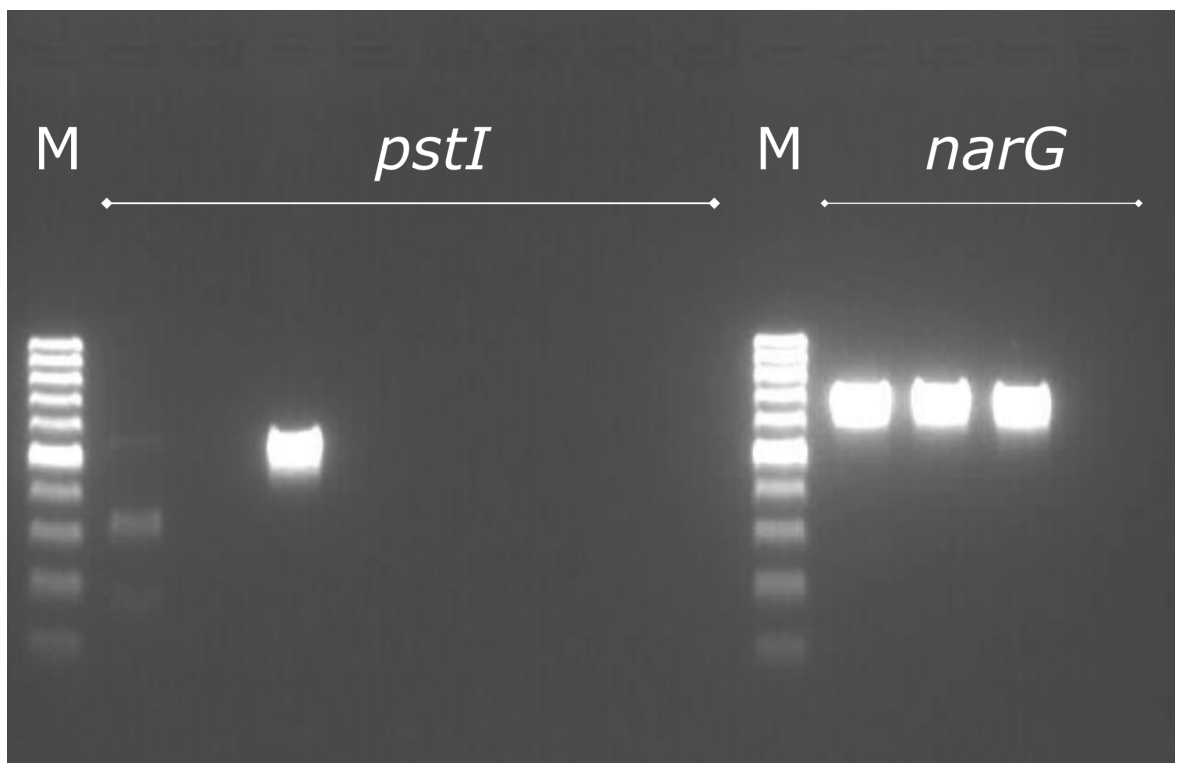

Fig. 3. Gel electrophoresis of PCR products with the following primers: ptsI_F_ptsI_R and narG_F_ narG_R. M is a GeneRuler 100 bp DNA Ladder (Thermo Fisher Scientific; USA) (example)

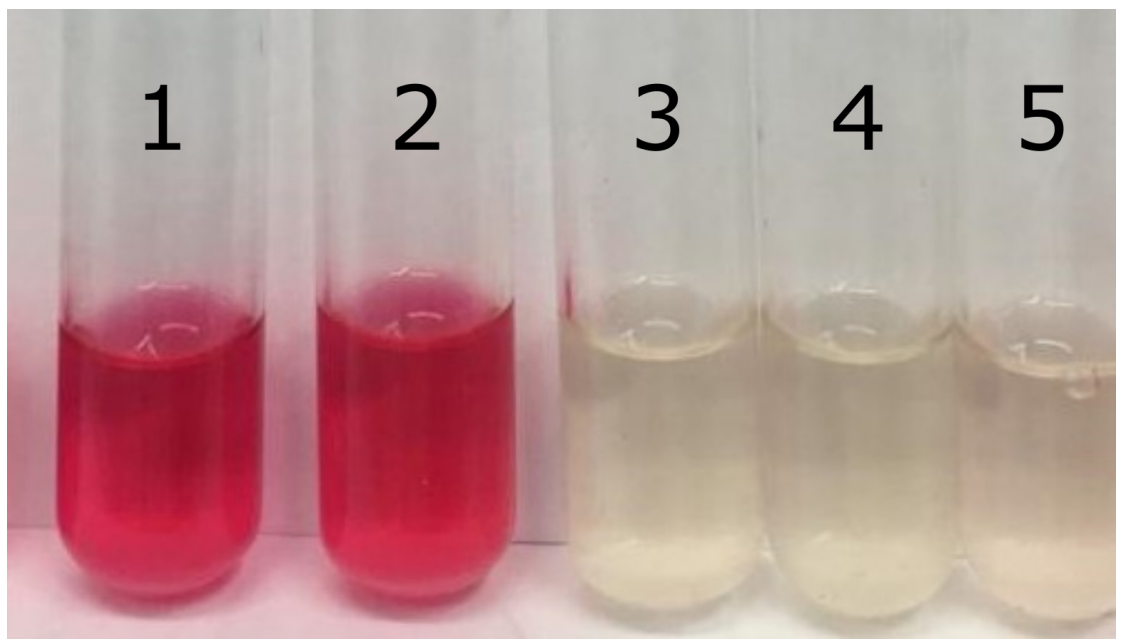

Fig. 4. Saccharolytic acivity of $C$. diphtheriae subsp. lausannense strains: the ability to ferment $\mathrm{N}$-acetylglucosamine. The crimson color of the medium means the test results are positive. 1, 2 are isolated strains of $C$. diphtheriae subsp. lausannense; 3 is a strain of gravis $C$. diphtheriae subsp. diphtheriae; 4 is a strain of mitis C. diphtheriae subsp. diphtheriae; 5 - negative control 


\section{DISCUSSION}

We were able to identify the two analyzed $C$. diphtheriae strains isolated from the samples of Russian residents as nontoxigenic representatives of subsp. lausannense. Our findings along with the reports of foreign researchers $[14,22]$ suggest that these strains are ubiquitous. They belong to the sequence type ST199, which is part of the lineage-2 cluster typical to the lausannense subspecies, and carry the sequence of the $d t x R$ gene characteristic of lausannense representatives. The analysis of ortholog groups established the existence of loci specific to the subspecies of $C$. diphtheriae: the region containing the genes of the $\mathrm{N}$-acetylglucosaminephosphotransferase system (specific to the lausannense subspecies) and the region encoding the synthesis of nitrate reductase subunits (specific to the diphtheriae subspecies). Our findings are consistent with the results of earlier genomic studies of the lausannense subspecies [15] and the studies of the biochemical properties of the belfanti biotype [9, 10]. Primers designed for these genes and the subsequent PCR allowed us to classify the two analyzed strains as C. diphtheriae subsp. lausannense.

\section{CONCLUSIONS}

We have identified the 2 analyzed strains collected on the territory of Russia as nontoxigenic strains of $C$. diphtheriae subsp. lausannense. Our findings expand the knowledge of the biological diversity of $C$. diphtheriae and indicate the need for estimating the spread of these microorganisms

\section{References}

1. World Health Organization. Diphtheria reported cases. Available from: http://apps.who.int/immunization_monitoring/ globalsummary/timeseries/tsincidencediphtheria.html.

2. Yakimova TN, Markina SS, Maksimova NM. Difteriya segodnya. ZNiSO. 2013; 249 (12): 18-9. Russian.

3. O zabolevaemosti difteriey i sostoyanii antitoksicheskogo protivodifteriynogo immuniteta naseleniya Rossii. Information letter № 02/14390-2019-27 from 10.10.2019. Federal Service for Surveillance on Consumer Rights Protection and Human Wellbeing (Rospotrebnadzor). Russian.

4. Romney MG, Roscoe DL, Bernard K, Lai S, Efstratiou A Clarke AM. Emergence of an invasive clone of nontoxigenic Corynebacterium diphtheriae in the urban poor population of Vancouver, Canada. J Clin Microbiol. 2006 May; 44 (5): 1625-9.

5. Hirata J, Pereira GA, Filardy AA, Gomes DLR, Damasco PV, Rosa ACP, et al. Potential pathogenic role of aggregativeadhering Corynebacterium diphtheriae of different clonal groups in endocarditis. Brazilian J Med Biol Res. 2008; 41 (11): 986-91.

6. Gubler J, Huber-Schneider C, Gruner E, Altwegg M. An Outbreak of Nontoxigenic Corynebacterium diphtheriae Infection: Single Bacterial Clone Causing Invasive Infection Among Swiss Drug Users. Clin Infect Dis. 1998 Nov; 27 (5): 1295-8.

7. FitzGerald RP, Rosser AJ, Perera DN. Non-toxigenic penicillinresistant cutaneous $\mathrm{C}$. diphtheriae infection: A case report and review of the literature. J Infect Public Health. 2015 Jan 1; 8 (1): 98-100.

8. Edwards B, Hunt AC, Hoskisson PA. Recent cases of nontoxigenic Corynebacterium diphtheriae in Scotland: Justification for continued surveillance. Journal of Medical Microbiology. 2011; (60): 561-2.

9. Funke G, Von Graevenitz A, Clarridge JE, Bernard KA. Clinical microbiology of Coryneform bacteria. Clinical Microbiology Reviews. 1997; (10): 125-59.

10. Bernard KA, Funke G. Corynebacterium. In: Bergey's Manual of Systematics of Archaea and Bacteria. Chichester, UK: John Wiley \& Sons, Ltd, 2015; p. 1-70.

11. Trost E, Blom J, de Soares SC, Huang $\mathbb{H}$, Al-Dilaimi A, Schröder J, et al. Pangenomic study of Corynebacterium diphtheriae that provides insights into the genomic diversity of pathogenic isolates from cases of classical diphtheria, endocarditis, and pneumonia. J Bacteriol. 2012; 194 (12): 3199-215

12. Sangal V, Burkovski A, Hunt AC, Edwards B, Blom J, Hoskisson PA. A lack of genetic basis for biovar differentiation in clinically important Corynebacterium diphtheriae from whole genome sequencing. Infect Genet Evol. 2014; 21 (November): 54-7.

13. Sangal V, Hoskisson PA. Evolution, epidemiology and diversity of Corynebacterium diphtheriae: New perspectives on an old foe. Infect Genet Evol. 2016; (43): 364-70.

14. Bolt F, Cassiday P, Tondella ML, DeZoysa A, Efstratiou A, Sing A, et al. Multilocus Sequence Typing Identifies Evidence for Recombination and Two Distinct Lineages of Corynebacterium diphtheriae. J Clin Microbiol. 2010; 48 (11): 4177-85.

15. Tagini F, Pillonel T, Croxatto A, Bertelli C, Koutsokera A, Lovis A, et al. Distinct genomic features characterize two clades of Corynebacterium diphtheriae: Proposal of Corynebacterium diphtheriae Subsp. diphtheriae Subsp. nov. and Corynebacterium diphtheriae Subsp. lausannense Subsp. nov. Front Microbiol. 2018 Aug 17; (9): 1743

16. Li L, Stoeckert CJ, Roos DS. OrthoMCL: identification of ortholog groups for eukaryotic genomes. Genome Res. 2003; 13 (9): 2178-89

17. Edgar RC. MUSCLE: multiple sequence alignment with high accuracy and high throughput. Nucleic Acids Res. 2004; 32 (5): $1792-7$

18. Price MN, Dehal PS, Arkin AP. FastTree 2 - Approximately maximum-likelihood trees for large alignments. PLoS One. 2010 Mar 10; 5 (3)

19. Nascimento M, Sousa A, Ramirez M, Francisco AP, Carriço JA, Vaz C. PHYLOViZ 2.0: Providing scalable data integration and visualization for multiple phylogenetic inference methods. Bioinformatics. 2017; 33 (1): 128-9.

20. Nakao H, Mazurova IK, Glushkevich T, Popovic T. Analysis of heterogeneity of Corynebacterium diphtheriae toxin gene, tox, and its regulatory element, $\mathrm{dtxR}$, by direct sequencing. Res Microbiol. 1997; 148 (1): 45-54.

21. Chagina IA, Perevarova YuS, Perevarov W, Chaplin AV, Borisova OYu, Kafarskaya LI, et al. Polymorphism of the $\mathrm{dtxR}$ gene in the currently existing strains of Corynebacterium diphtheriae. Bulletin of RSMU. 2017; (1): 31-37.

22. Farfour E, Badell E, Dinu S, Guillot S, Guiso N. Microbiological changes and diversity in autochthonous non-toxigenic Corynebacterium diphtheriae isolated in France. Clin Microbiol Infect. 2013; 19 (10): 980-7.

\section{Литература}

1. World Health Organization. Diphtheria reported cases. Available from: http://apps.who.int/immunization_monitoring/ globalsummary/timeseries/tsincidencediphtheria.html.

2. Якимова Т. Н., Маркина С. С., Максимова Н. М. Дифтерия сегодня. ЗНиСО. 2013; 249 (12): 18-9.
3. О заболеваемости дифтерией и состоянии антитоксического противодистерийного иммунитета населения России. Информационное письмо № 02/14390-2019-27 от 10.10.2019. Федеральная служба по надзору в сфере защиты прав потребителей и благополучия человека (Роспотребнадзор). 
Russian.

4. Romney MG, Roscoe DL, Bernard K, Lai S, Efstratiou A, Clarke AM. Emergence of an invasive clone of nontoxigenic Corynebacterium diphtheriae in the urban poor population of Vancouver, Canada. J Clin Microbiol. 2006 May; 44 (5): 1625-9.

5. Hirata J, Pereira GA, Filardy AA, Gomes DLR, Damasco PV, Rosa ACP, et al. Potential pathogenic role of aggregativeadhering Corynebacterium diphtheriae of different clonal groups in endocarditis. Brazilian J Med Biol Res. 2008; 41 (11): 986-91.

6. Gubler J, Huber-Schneider C, Gruner E, Altwegg M. An Outbreak of Nontoxigenic Corynebacterium diphtheriae Infection: Single Bacterial Clone Causing Invasive Infection Among Swiss Drug Users. Clin Infect Dis. 1998 Nov; 27 (5): 1295-8.

7. FitzGerald RP, Rosser AJ, Perera DN. Non-toxigenic penicillinresistant cutaneous $\mathrm{C}$. diphtheriae infection: $\mathrm{A}$ case report and review of the literature. J Infect Public Health. 2015 Jan 1; 8 (1): 98-100.

8. Edwards B, Hunt AC, Hoskisson PA. Recent cases of nontoxigenic Corynebacterium diphtheriae in Scotland: Justification for continued surveillance. Journal of Medical Microbiology. 2011; (60): 561-2.

9. Funke G, Von Graevenitz A, Clarridge JE, Bernard KA. Clinical microbiology of Coryneform bacteria. Clinical Microbiology Reviews. 1997; (10): 125-59.

10. Bernard KA, Funke G. Corynebacterium. In: Bergey's Manual of Systematics of Archaea and Bacteria. Chichester, UK: John Wiley \& Sons, Ltd, 2015; p. 1-70.

11. Trost E, Blom J, de Soares SC, Huang $\mathbb{H}$, Al-Dilaimi A, Schröder J, et al. Pangenomic study of Corynebacterium diphtheriae that provides insights into the genomic diversity of pathogenic isolates from cases of classical diphtheria, endocarditis, and pneumonia J Bacteriol. 2012; 194 (12): 3199-215.

12. Sangal V, Burkovski A, Hunt AC, Edwards B, Blom J, Hoskisson PA. A lack of genetic basis for biovar differentiation in clinically important Corynebacterium diphtheriae from whole genome sequencing. Infect Genet Evol. 2014; 21 (November): 54-7.

13. Sangal V, Hoskisson PA. Evolution, epidemiology and diversity of
Corynebacterium diphtheriae: New perspectives on an old foe. Infect Genet Evol. 2016; (43): 364-70.

14. Bolt F, Cassiday P, Tondella ML, DeZoysa A, Efstratiou A, Sing A, et al. Multilocus Sequence Typing Identifies Evidence for Recombination and Two Distinct Lineages of Corynebacterium diphtheriae. J Clin Microbiol. 2010; 48 (11): 4177-85.

15. Tagini $F$, Pillonel $T$, Croxatto A, Bertelli $C$, Koutsokera A, Lovis A, et al. Distinct genomic features characterize two clades of Corynebacterium diphtheriae: Proposal of Corynebacterium diphtheriae Subsp. diphtheriae Subsp. nov. and Corynebacterium diphtheriae Subsp. lausannense Subsp. nov. Front Microbiol. 2018 Aug 17; (9): 1743.

16. Li L, Stoeckert CJ, Roos DS. OrthoMCL: identification of ortholog groups for eukaryotic genomes. Genome Res. 2003; 13 (9): 2178-89.

17. Edgar RC. MUSCLE: multiple sequence alignment with high accuracy and high throughput. Nucleic Acids Res. 2004; 32 (5): 1792-7.

18. Price MN, Dehal PS, Arkin AP. FastTree 2 - Approximately maximum-likelihood trees for large alignments. PLoS One. 2010 Mar 10; 5 (3)

19. Nascimento M, Sousa A, Ramirez M, Francisco AP, Carriço JA, Vaz C. PHYLOViZ 2.0: Providing scalable data integration and visualization for multiple phylogenetic inference methods. Bioinformatics. 2017; 33 (1): 128-9.

20. Nakao H, Mazurova IK, Glushkevich T, Popovic T. Analysis of heterogeneity of Corynebacterium diphtheriae toxin gene, tox, and its regulatory element, $\mathrm{dtxR}$, by direct sequencing. Res Microbiol. 1997; 148 (1): 45-54.

21. Chagina IA, Perevarova YuS, Perevarov W, Chaplin AV, Borisova OYu, Kafarskaya LI, et al. Polymorphism of the $\mathrm{dtxR}$ gene in the currently existing strains of Corynebacterium diphtheriae. Bulletin of RSMU. 2017; (1): 31-37.

22. Farfour E, Badell E, Dinu S, Guillot S, Guiso N. Microbiological changes and diversity in autochthonous non-toxigenic Corynebacterium diphtheriae isolated in France. Clin Microbiol Infect. 2013; 19 (10): 980-7. 